https://doi.org/10.25143/socr.14.2019.2.073-080

\title{
Criminal Activity as Preoccupation Challenging the State of Estonia, now 100
}

\author{
Ando Leps \\ Dr. iur., professor emeritus \\ Member of VIII and IX compositions of \\ Riigikogu (Parliament), Estonia
}

\begin{abstract}
In connection with the $100^{\text {th }}$ anniversary of the Republic of Estonia, it is proper and pertinent to compose synopsis of infractions of law (criminal activity) committed in those years. Since 2003, the rather complicated but most rewarding work has been the responsibility of Ministry of Justice, which also releases publications on criminal activity. ${ }^{1}$

Keywords: criminal actions, Estonia, intentional homicides, first degree murders, voluntary manslaughters, money laundering.

\section{General notes}

Society or "civil society", the phrase enamoured by Hegel, as well as the state have a fixed organisational structure set forth by universal juridical laws. Nevertheless, in every state those operate differently impressed by unique nationalist specificity and historical experience indigenous and sui generis to every person. One cannot but remember that every historical epoch is the follow-up of temporal precedent, even if the subsequent epoch appears being exceedingly negative regarding previous temporal periods. Thence the present infractions of law (criminal activity) are nolens volens related to bygone infractions of law (criminal activity).

Property relations applied in the process of social production of people underlie the power relation, and their change triggers adoption of new juridical laws, their amendment and complementation, which in its turn impinges on criminal statistics,
\end{abstract}

\footnotetext{
${ }^{1}$ Criminal policy surveys "Criminal activity in Estonia in 2018”, Tallinn, 2018.
} 
i. e. structure, dynamics and level of criminal activity. Therefore, crimes attacking people's life, health and property, as a form of activity spearheaded against juridical laws, reflect the time of their perpetration and foundations of social production and exchange, as well as living conditions of members of society.

None of the statistics is "quite" right. It is perhaps through statistics, which is essentially by and large evidentiary that the famed A. Einstein arrived at his probability theory.

This short article by the subscriber has attempted to convey only the most important. Statistics of 1919-1938 has been especially "smoothed out", particularly regarding infractions of law or misdemeanours, in order to render them more or less comparable both within their corpus and with numerical data of other contrasted years.

The Penal Law of 1935 just partially rectified such an error. The reasons for the created "confusion" are difficult to trace and might be the cause of political interference.

Whereas one cannot but mention that the lawyer as a member of society, as a contemporary of the historical epoch, possessing certain philosophical, economical, political and other views must first be honest to himself or herself and to science.

\section{Criminal activity}

The overview on change in number of criminal actions registered in Estonian law enforcement agencies in 1919-2018 (data on time interval 1939-1944 are missing) is provided in Figure 1 (the lower line for 1919-1938 excludes violations of administrative regulations), with criminal activity curve showing in the first place criminal actions committed by employees and unemployed (usually average and poorer layers of population).

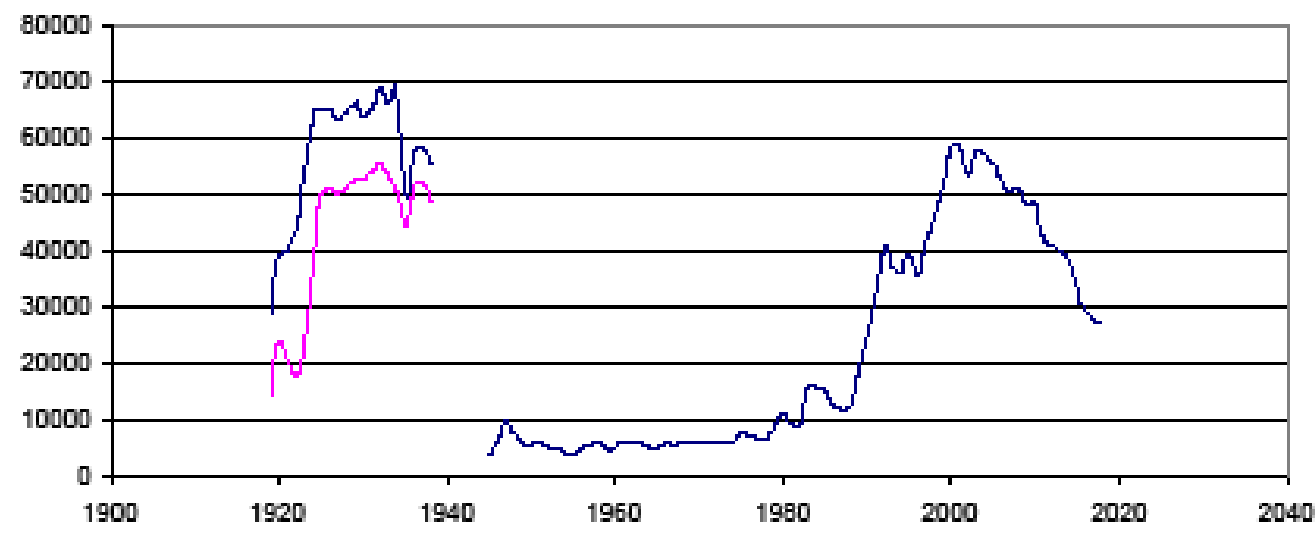

Figure 1. Criminal actions registered in Estonian law enforcement agencies in 1919-2018 2

2 All figures have been drawn by Galina Bibikova. 
On the contrary, criminal actions (professional and white-collar criminal actions) of employers, civil servants and municipal officers (usually wealthier layers of population) are not reflected in criminal statistics.

Analysis of criminal actions registered in law enforcement agencies reveals that the level of criminal activity in "canonical" Soviet period, i.e. in years 1950-1980 was eight times lower than in years 1919-1938 and in Estonia's regained independence period (1992-2000) and nine times lower than in the incipient years of this century. It may be more appropriate to say that in the mentioned years in was less by orders of magnitude. The largest ever number of criminal actions in Estonia was registered in $2001-58,497$ criminal actions (see Figure 2).

That difference cannot be explained by possible transmogrification of criminal activity registered in the Soviet period militia (that is the pestilent inherent in all countries), because at the time a relatively small income discrepancy was dealt with due to levelling-off policy and society almost lacking unemployment. Evidently work of militia was not worse either than that of the regained independence period police; conducive to discovery of criminal actions (presently police clear-up rate) was also openness of the totalitarian society before the state.

Nevertheless, in Soviet period criminal activity grew. Since it no longer befitted the dominant ideology, under which the development of socialism was supposed to decrease the level of criminal activity, the data on criminal activity were stamped secret.

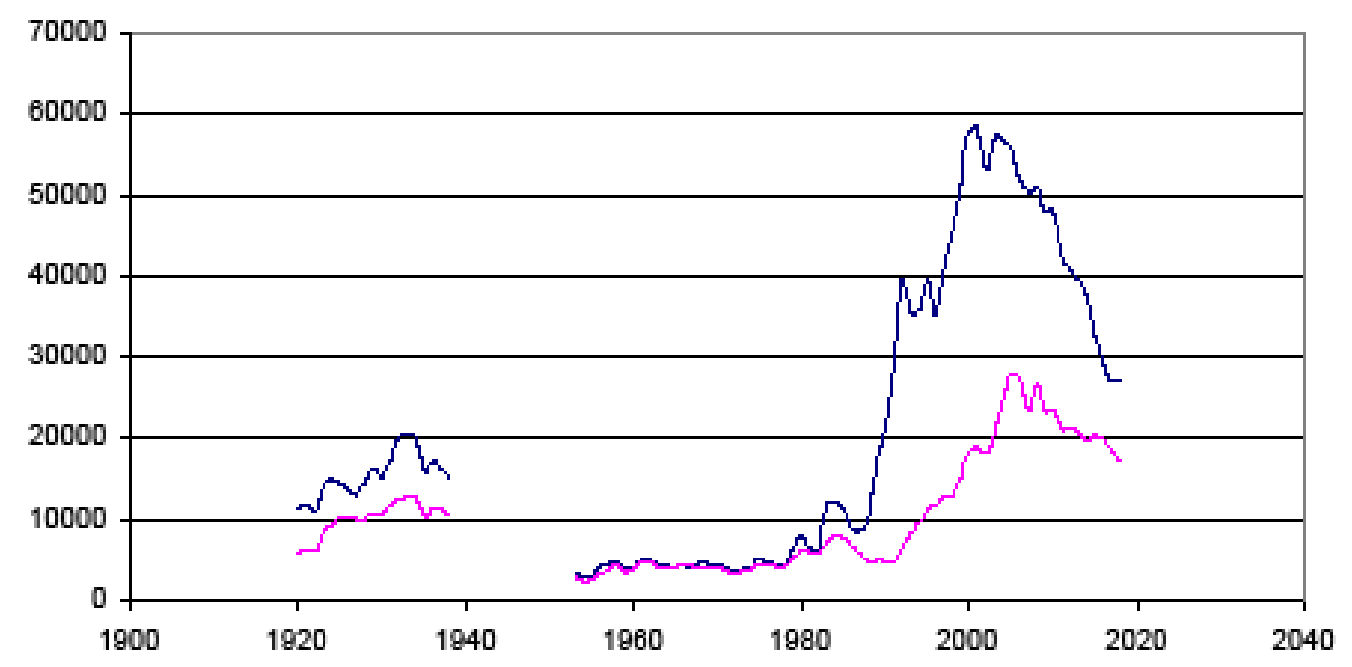

Figure 2. Clearing of crime (a charge being laid) in law enforcement agencies in 1920-2018 (police clear-up rate) 
The author of this article was among the first innovative lawyers in the world in 1991 contrasting criminal activity of various countries, the most heinous of crimes, i.e. crime located at the apex of the "pyramid" of criminal activity - intentional homicide, and with its help compared criminal activity of 95 states of the world (with some states disclosing the data on their criminal activity), as well as criminal activity of continents and different regions. Such a method can also be applied based on historical aspect (see Figures 1 and 3), which would allow noticing that in the "canonical" Soviet period intentional homicides were relatively rare. ${ }^{3}$

Spectacular rise of the number of intentional homicides was evidenced in Estonia in the so-called transitional period (1990-1998). For example, in 1992 there was registered a record number of intentional homicides and attempted murders -239 . It was the flourish of the so-called rapacious capitalism, with one enriching through crime (creating the class of owners, i.e. capitalists), while juridical laws often "fell silent" as in wartime in ancient Rome. In recent years, the number of intentional homicides, first degree murders and voluntary manslaughters has noticeably decreased; however, the number of personal criminal actions has soared.

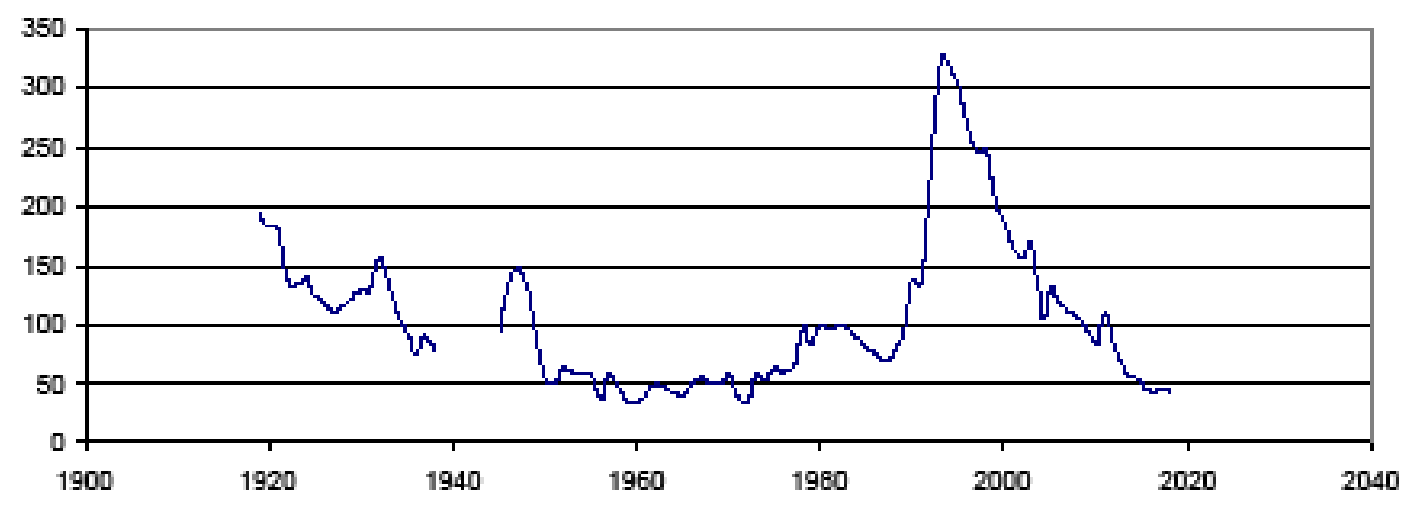

Figure 3. Intentional homicides (first degree murders, voluntary manslaughters) and attempt murders registered in Estonian law enforcement agencies in 1919-2018

Estonia's regained independence has brought about a lot of problems, besides home rule and freedom: economic hardship, property stratification of population and unemployment. Provided background allowed the flourishing of criminal activity, with the state power struggling to provide security to citizens fearful of being burgled. Since 2003, the number of criminal actions has shrunk, but in 2018 it happened mainly on account of property crime $-28 \%$. Criminal activity is essentially an activity targeted at property in violation of juridical laws, with personal thefts (e.g. smash-and-grab raids)

${ }^{3}$ Ando Leps. Kuritegevus Eestis. Tartu: Tartu Ülikool, Eesti Akadeemiline Õigusteaduse Selts, 1991. (Criminal Activity in Estonia. Tartu: University of Tartu, Estonian Academic Law Society, 1991.) 
Ando Leps. Criminal Activity as Preoccupation

Challenging the State of Estonia, now 100

presenting the largest share. Because theft at 200 euros (20 minimum daily rates) is no longer a criminal action but a mere misdemeanour, criminal activity will naturally drop, since the predominant share of registered criminal actions is constituted by thefts.

\section{Inmates}

In the Soviet period, the number of inmates was much higher than in other periods (see Figure 4), caused by rather long incarceration terms and understanding that in correctional facilities inmates are "reformed" or re-educate themselves. Between 1921-1935, inmates averaged 3270, between 1966-1991 - 4800, in the years 1992-2007 they were 2810 individuals, in 2008-2012 - 3480 individuals and in 2013-2017 - 2925 individuals. It must be admitted that only Figure 3 presents numerical data on 10 thousand inmates, which illustrates unidirectional movement of the number of inmates and population towards decrease. Internationally the inmate ratio per 100 thousand residents is used; the average ratio in Estonia has been: in the years 1921-1935 - 276 individuals, in 1966-1991 - 323 individuals, in 1992-2007 - 213 individuals, in 2000-2008 - 323 individuals and in 2012-2018 - 230 individuals. Therefore, as per 100 thousand residents the inmate ratio has significantly decreased in recent years.

In Estonian prisons (penitentiaries) and houses of detention (jails) there were, by the end of 2018, 2584 detainees, of whom 2040 were convicted in courts, 530 in custody and 14 apprehended for misdemeanour and were placed under arrest.

In 2016, in the European Union Member states there were as per 100 thousand residents on average 124 inmates, in Estonia that number was 191, in Latvia - 224, in Lithuania - 254, in Russia - 416, but in Finland - 57, in Sweden - 58 and in Norway - 73.

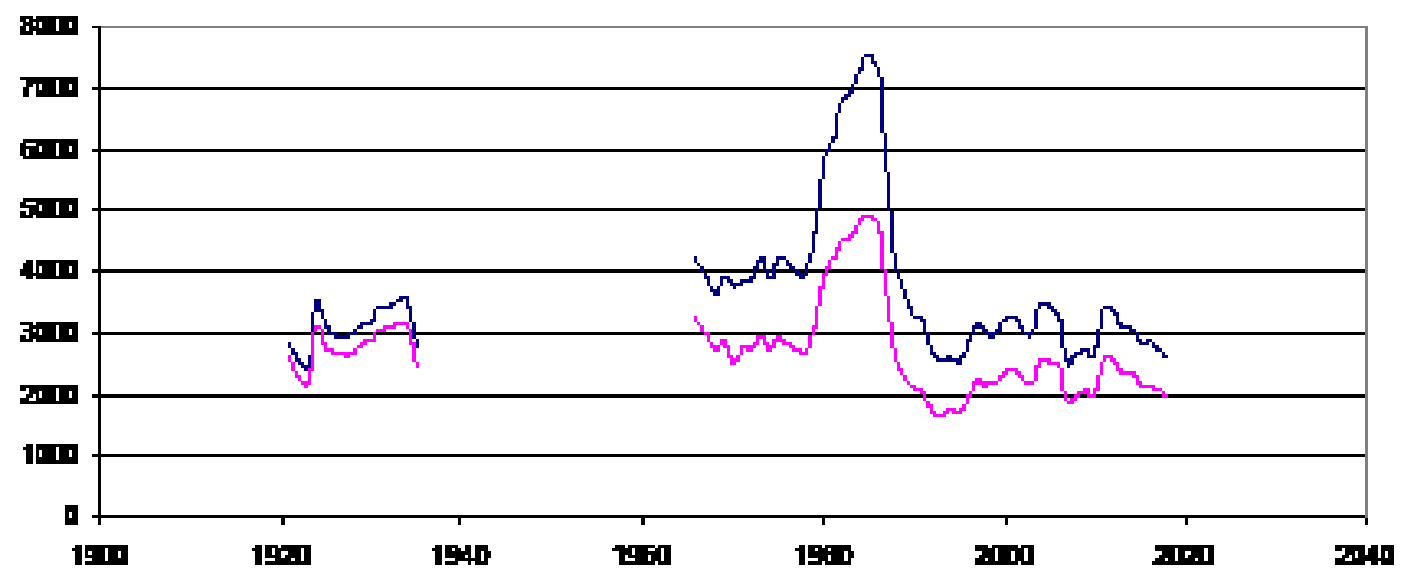

Figure 4. Number of persons convicted by courts in Estonian prisons and their ratio as per 10000 residents in $1921-2018$ 
At the end of 2018, there were 14 minors in prison, of whom 10 convicted and 4 in custody. The number of minor inmates staying in prison has decreased, i.e. by the end of 2018 minor inmates were halved compared to two years previously. There were no 14-year-olds in prison, there were two 15-year-olds, five 16-year-olds and seven 17-yearolds. Majority of minors land in prison for property crime.

By the end of 2018, there were 2461 male (95\%) and 123 female (5\%) inmates; the number of Estonian citizens 1662 (64\%), Russian citizens - 177 (7\%), persons of undefined citizenship - 677 (26\%).

Throughout the year the distribution of inmates did not change significantly as per citizenship. Prisons held citizens from other countries: Latvia (24), Lithuania (9), Ukraine (7), Finland (4), Serbia (3); as well as citizens (one from every state) of Afghanistan, Azerbaijan, Georgia, Netherlands, Kazakhstan, Moldova, Poland, Portugal, Great Britain, Syria, Tunis, Uzbekistan, Belarus.

The share of Estonian speaking inmates has remained at the same level as compared to the earlier: in 2018 - 1031 (40 \%) - and in 2017 - 1037 (41 \%). At the end of 2018, the share of Russian speaking inmates was 1353 (52\%).

At the end of 2018, Estonian prisons hosted 42 persons sentenced for life (2\%), $3 \%$ of inmates had to serve over 15 years, $8 \%$ had been incarcerated for $10-15$ years, $24 \%$ of inmates were incarcerated for 5-10 years, $52 \%$ of inmates were imprisoned for only $1-5$ years and $11 \%$ were jailed for a period within one year.

In 2018, 1907 persons were released from prison as convicted criminals. In connection with serving their time, 764 convicted criminals or $40.1 \%$ of those released from prison were set free. As compared to 2016 and 2017, the share of inmates set free under criminal probation has significantly increased, either set free under suspended sentence (560 persons or $29.4 \%$ ) or by serving partially the sentenced incarceration i.e. by the socalled shock incarceration (387 persons or $20.3 \%$ ).

\section{Summary}

The past. Estonian Law enforcement agencies registered the smallest number of criminal actions in the "canonical" Soviet period. That fact is corroborated by low numbers of intentional homicides and attempted murders (presented in Figure 2). Most importantly that period is characterised by low degree of property stratification and practically non-existent unemployment, resulting in better relations between individuals as compared with the situation evidenced today.

The present. The early stage of capitalist society, rapacious capitalism, naturally brought about in Estonia a steep rise in criminal activity; however, in recent years the tide of criminal activity has stemmed, caused mainly by decrease of property crime. The number of personal criminal actions, however, has grown, while the number of intentional homicides, first degree murders and voluntary manslaughters has dropped, 
although within Europe the level of Estonian, Latvian and Lithuanian intentional homicide and first degree murders per 100 thousand residents for 2016 were very high (Russia - 10.8; Lithuania - 5.3; Latvia - 3.4; Estonia - 3.2; Finland - 1.4; Sweden - 1.1; Norway - 0.5), wherefore the levels of criminal activity of those states per 100 thousand residents in 2014: Estonia - 287; Lithuania - 283 and Latvia - 239 seem to be too modest. Meanwhile, in countries of high living standard such as Finland, Sweden, Norway, the level of criminal activity is significantly higher than in Estonia.

Special concerns in Estonia are: 1) rampant use of narcotics, first putting our youth in peril and then endangering the existence of the whole nation; 2) number of corrupt criminal activity in 2018 increased by 23 \% compared to 2017; 3) money laundering; 4) family violence was registered in 2018 by $37 \%$ more compared to 2017; 5) traffic safety generally and especially traffic criminal actions, often perpetrated by inebriated and intoxicated drivers of motor vehicles. In 2017, it proved that Estonian banks were the "thoroughfare" of dirty money - 1.6 billion \$US, e.g. through Danske Bank's Estonian branch -1.8 billion and through Versobank - 205 million, through Eesti Krediidipank 121 million, through SEB Pank - 32 million, of unknown origin - 37 million dollars (Postimees 20.03.2017). But these sums of money are not accurate.

The future. Globalisation, controversial understanding of democracy, instability of world economy, uncontrollable population growth in the world and terrorism present a particular "appeal" to a number of great powers evidently to divert attention from topical social sore points, consequently also from causes of criminal activity, such as problems related to the rich and the poor and unemployment, which will evidently be related to further "developments" in criminal activity in Estonia.

\section{Noziedzība Igaunijā valsts rūpju lokā tās simtgadē}

\section{Kopsavilkums}

Svinot Igaunijas valsts simtgadi, nozīmīga ir arī ši laika perioda likumpārkāpumu (noziedzības) analīze. Neviena statiska nav pilnīgi precīza, tomēr tā dod iespēju atspoguḷot pašu būtiskāko. Noziedzības statisku valstī ietekmē normatīvās regulācijas izmaiṇas. Igaunijas statistikā laika periodā no 1900. līdz 2018. gadam ir t.s. "baltie plankumi" (piemēram, par 1939.-1944. gadu). Statistikas analīze parāda, ka padomju laika periodā (1950.-1980. gadā) noziedzība bija vairākas reizes zemāka nekā 1919.-1938. gadā un pēc Igaunijas valstiskās neatkarības atjaunošanas. Slepkavību analīze rāda, ka tās visvairāk tika regiistrētas 1990.-1998. gadā. Ieslodzīto skaits padomju laika periodā bija augsts, bet neatkarības gados tas pakāpeniski samazinās. Bet mainās noziegumu struktūra. Igaunijas noziedzības struktūrā pēdējos gados vairāk tiek reǵistrēti noziegumi, kas ir 
saistīti ar narkotiskām vielām, korupciju, vardarbību gimenē un ar celı satiksmes negadījumiem. Globalizācija, apstrīdama demokrātijas izpratne, nestabilā pasaules ekonomika, nekontrolējamais pasaules iedzīvotāju pieaugums un terorisms, īpašas "patikas" izrādīšana noteiktām valdošajām varām - tas viss novirza uzmanību no patiesām sociāla rakstura problēmām un no tām izrietošām turpmāk iespējamām krimināla rakstura darbībām Igaunijā.

Atslēgvārdi: Igaunija, noziedzības statistika, noziedzības analīze, tīšas slepkavības, korupcija, nelegāli iegūtas naudas atmazgāšana, vardarbība gimenē, ceḷu satiksmes negadijumi. 